\title{
Peripheral Osteoma in the Ramus of Mandible: Report of Case
}

\author{
Osteoma Periférico en la Rama Mandibular: Reporte de Caso
}

\author{
Nilton Alves ${ }^{*, * * * * *}$; Reinaldo José de Oliveira ${ }^{* * * *}$; Naira Figueiredo Deana ${ }^{* * * * *}$ \& Nelma Maria de Freitas
}

\begin{abstract}
ALVES, N.; OLIVEIRA, R. J.; DEANA, N. F. \& FREITAS, N. M. Peripheral osteoma in the ramus of mandible: Report of case. Int. J. Odontostomat., 5(3):215-219, 2011.

ABSTRACT: The osteomas are benign rare neoplasms, generally asymptomatic which are characterized by the proliferation of a compact or spongy bone. When they are situated in the maxillofacial area, they affect mainly the mandible, the frontal bone and the paranasal sinus. We have described the case of a female caucasian patient who presented an increased volume in the posterior region of the oral vestibule on the left side. During the clinical examination an oral lesion was observed in the region of the left ramus of mandible. This lesion was motionless, consistent, and painless when palpated. In the image obtained from the computed tomography cone-beam (CBCT), we could observe an hyperdense, cylindrical region, with well defined borders, located in the medial surface of the left ramus of mandible, right below the mandibular notch. Based on clinical data and in the obtained images, we could confirm the presence of the peripheral osteoma in the left side of the ramus of mandible region.
\end{abstract}

KEY WORDS: peripheral osteoma, computed tomography cone-beam, ramus of mandible.

\section{INTRODUCTION}

The osteomas are benign tumors formed mainly of mature compact or spongy bone (Regezi \& Sciubba, 2004). The isolated osteoma can be classified in: central (endosteal), peripheral (paraosteal, periosteal or exophytic) or extraskeletal (osseous choristoma) (Gardner \& Plenk, 1952).

The growing of the tumor is caused due to the activity of the periosteal or endosteal. The peripheral osteomas (PO) occur through the centrifugal growing from the periosteum, while the central osteomas (CO) appear centripetally from the endosteum (Sayan et al., 2002). These neoplasms are mostly found at the paranasal sinuses and in the mandible (Schneider et al., 1980; Sayan et al.; Larrea-Oyarbide et al., 2008).

The osteomas are rare neoplasms, from unknown etiology, with slow growing which can be found mostly between the second and fifth decades of life. However, they can also occur at any other age, and in relation to women, men are more affected by them (Kaplan et al., 1994; Regezi \& Sciubba).

The periosteal osteomas present themselves clinically as hard bone asymptomatic mass (Regezi \& Sciubba). When they cause any degree of asymmetry, they can interfere in the function and occlusion (Bodner et al., 1998; Larrea-Oyarbide et al.). In the radiographic exam, they appear as radiopaque, sclerotics and wellshaped mass (Regezi \& Sciubba).

In this study we described a case of PO in the region of the ramus of mandible, with radiographic image obtained through a Computed Tomography Cone-Beam (CTCB), with tri-dimensional reconstruction.

\footnotetext{
Universidade Estadual Paulista Júlio de Mesquita Filho, Araraquara, Brazil.

* Magíster en Ciencias, Mención Morfología, Universidad de la Frontera, Temuco, Chile.

*** Universidad de Talca, Talca, Chile.

*n+* Universidade Bandeirante de São Paulo, São Paulo, Brasil.

*trot* Fisioterapeuta, Brazil.

*tort+** Cirurgiã-dentista, Brazil.
} 


\section{CASE REPORT}

À 38-year-old caucasian female patient, complained about a volumetric increase in the posterior region on the left side of the oral vestibule. During clinical examination we noticed a tumoral lesion in the region of the ramus of mandible, on the left side, it was motionless and painless.
A panoramic radiography in which we noticed a radiopaque image in the left side of the ramus of mandible was carried out (Fig. 1). Posteriorly a CBCT was carried out, in which we could notice a radiodense, cylindrical, pediculated image, with well defined borders, in the medial surface on the left side of the

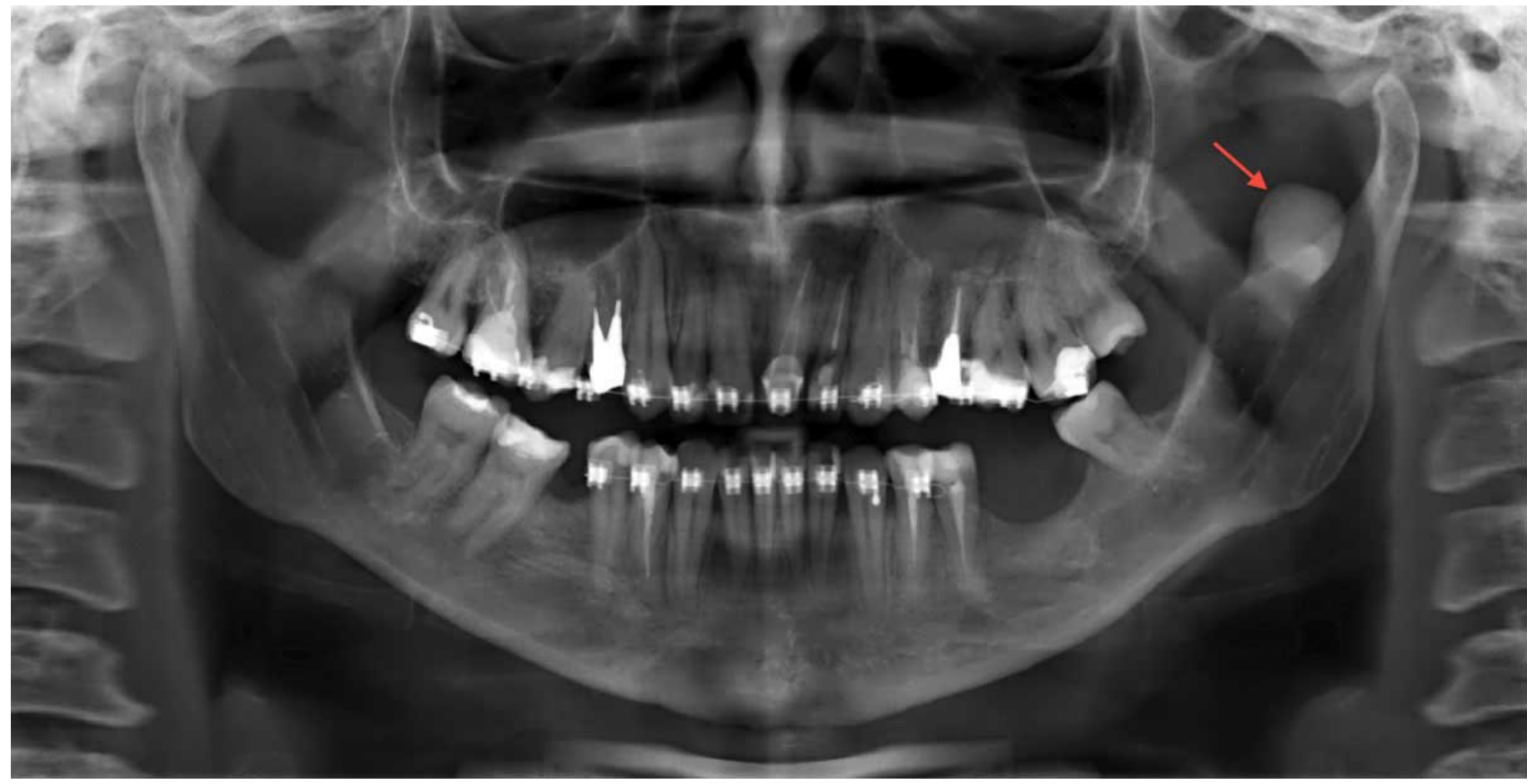

Fig. 1. Panoramic radiography showing a radiopaque image in the left ramus of mandible (arrow).

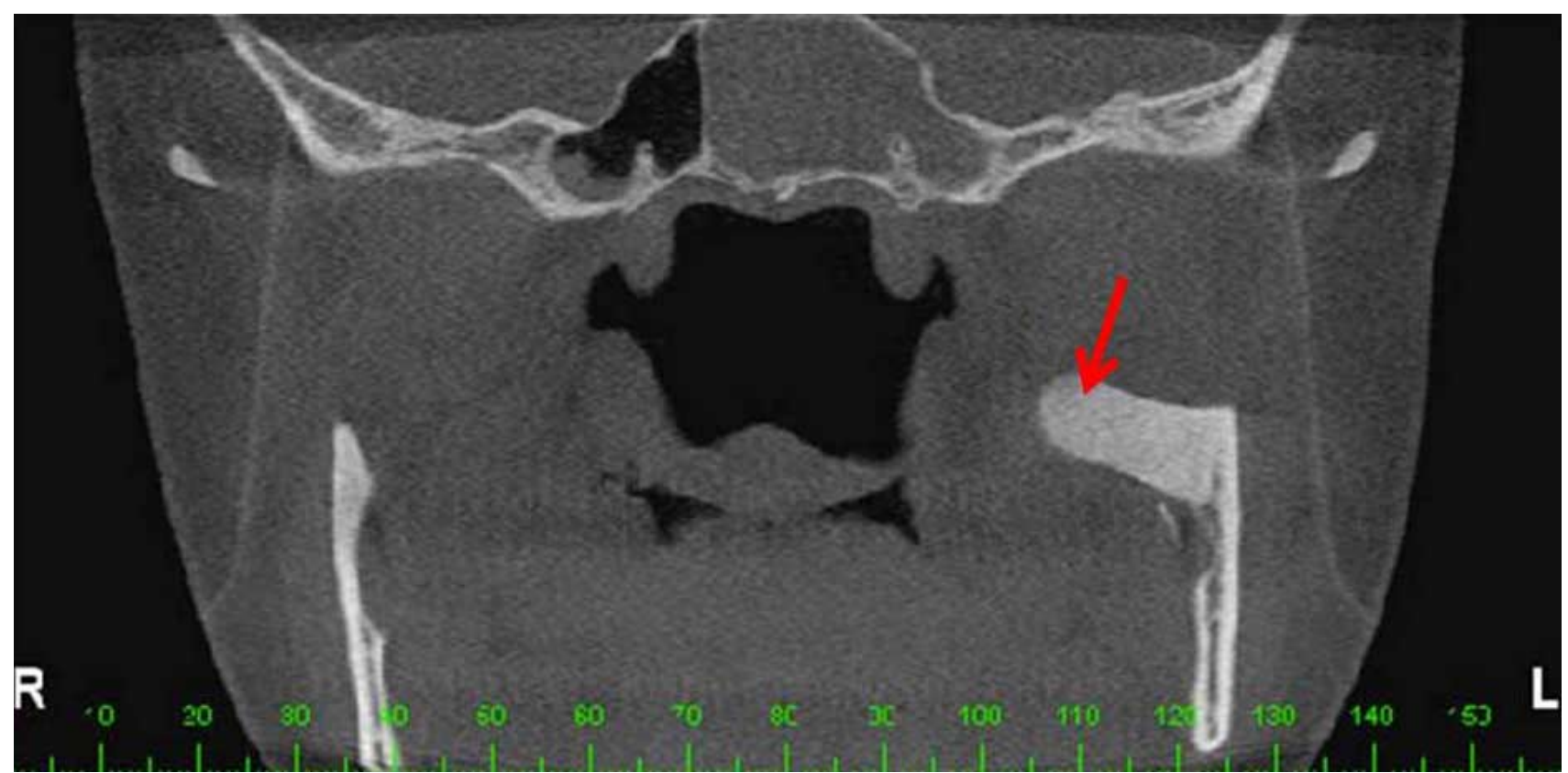

Fig. 2. Coronal CBCT scan showing radiodense image in the medial surface of the left ramus of mandible (arrow). 


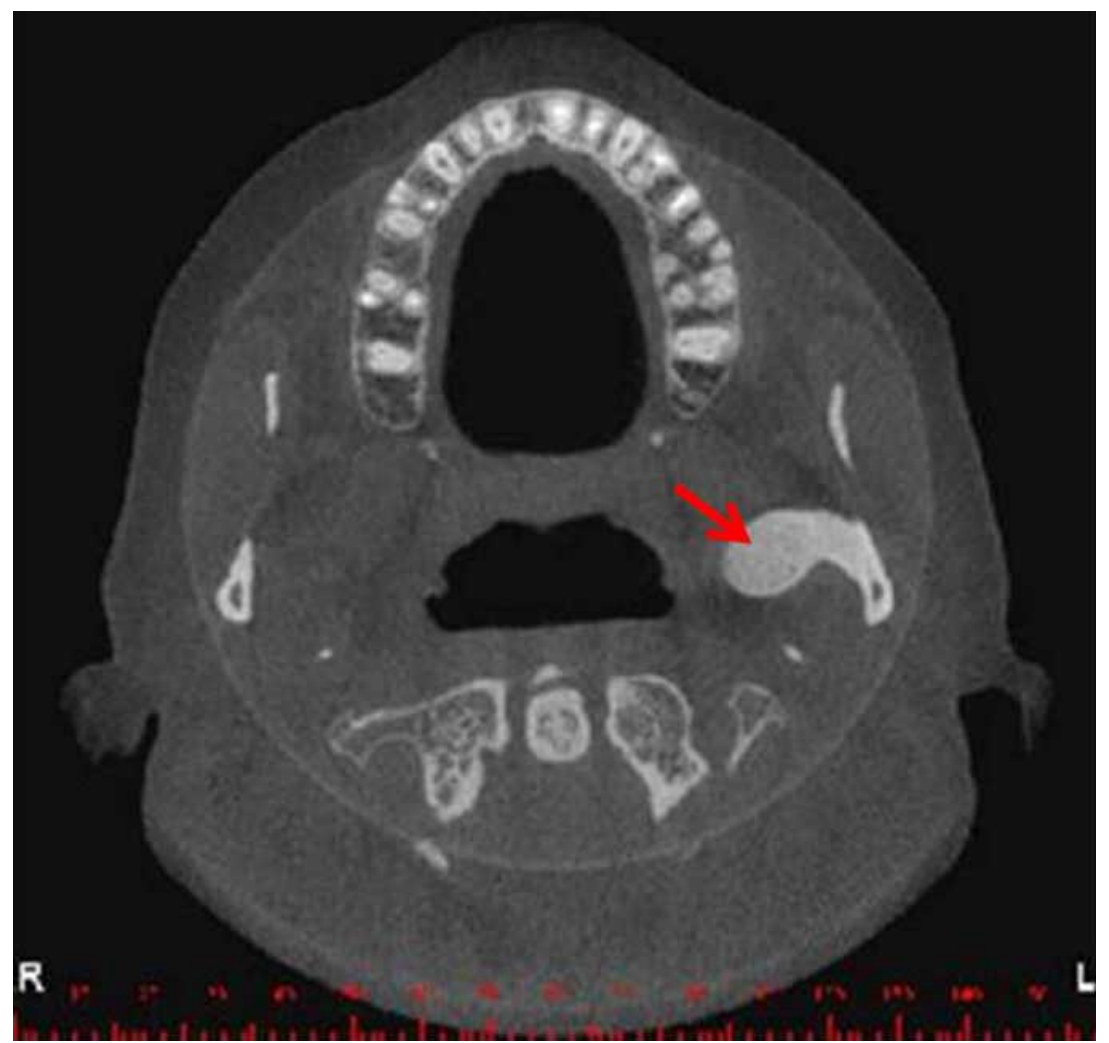

Fig. 3. Axial CBCT scan showing radiodense image in the medial surface of the left ramus of mandible (arrow). ramus of mandible, right below the mandibular notch compatible with the osteoma (Figs. 2 and 3). The tridimensional reconstruction was also accomplished (Figs. 4 and 5).

\section{DISCUSSION}

The peripheral osteomas are not common neoplasms. According to Schneider et al., Kaplan et al., Johann et al. (2005), Woldenberg et al. (2005), Cincik et al. (2007) and Larrea-Oyarbide et al. the region affected with more frequency is the mandible. However, Sayan et al. have found more cases of $\mathrm{PO}$ in the frontal bone, followed by the mandible and maxilla. According to Bodner et al. the PO occurs mostly at the paranasal sinuses and rarely reaches the bones of the cranium, they also claim that these lesions are less common in the mandible.

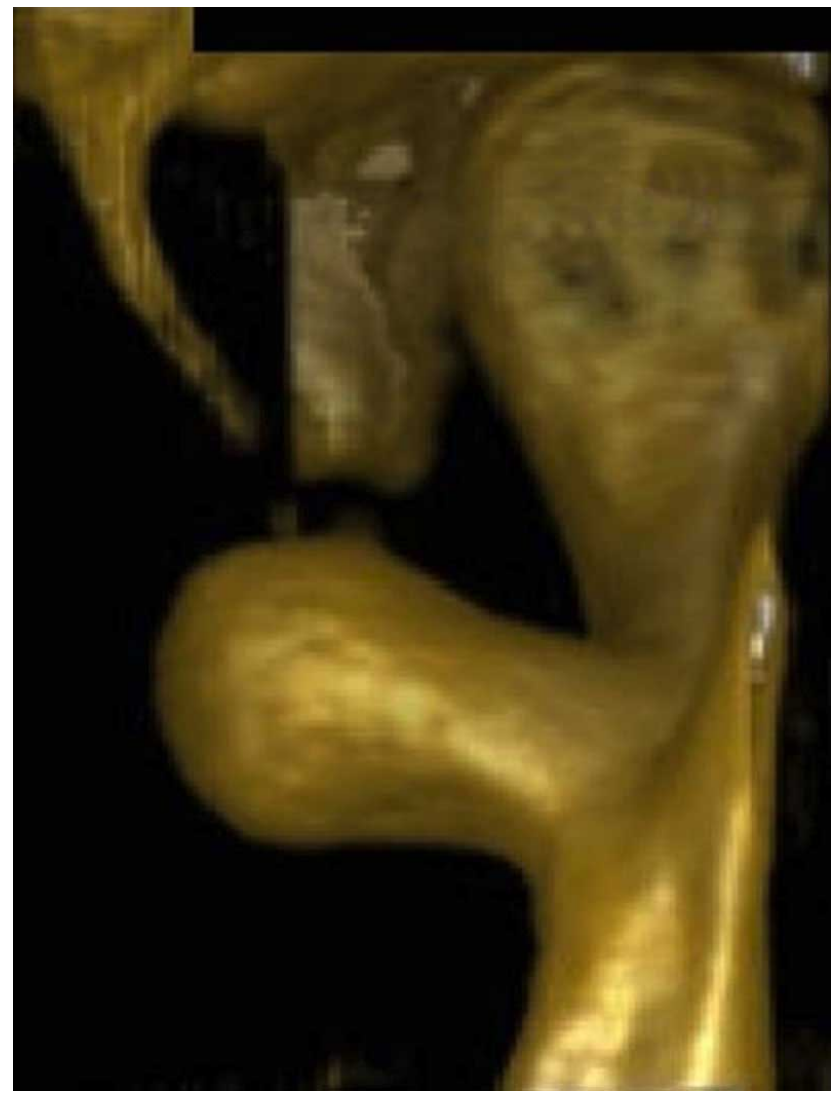

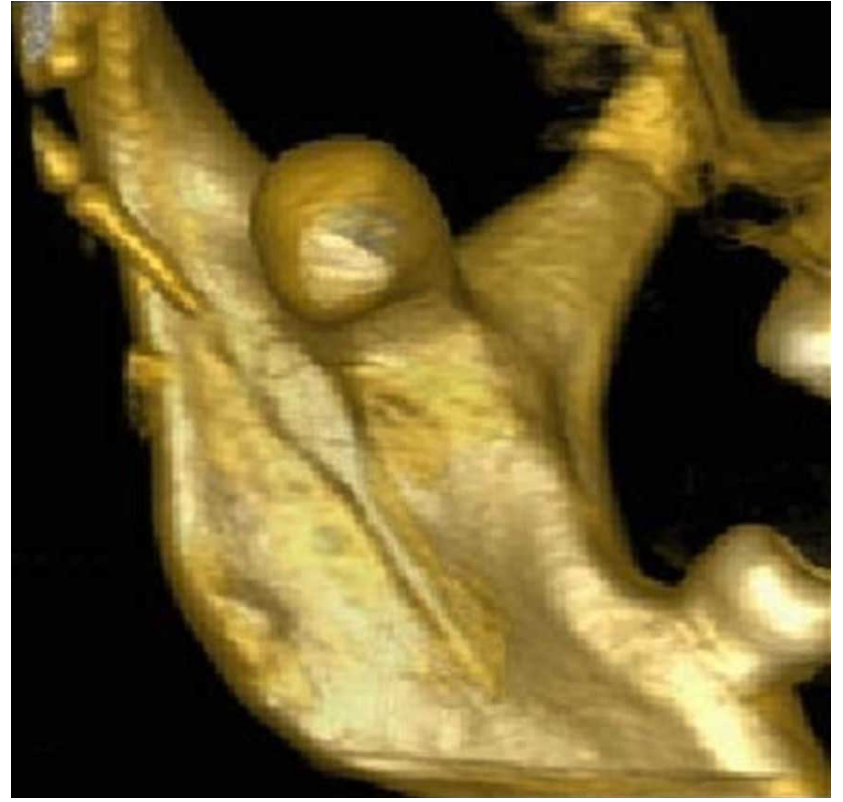

Fig. 4. Anterior view of the 3-D reconstruction. Fig. 5. Medial view of the 3-D reconstruction. 
When analyzing the osteomas, which occur in the mandible, the authors agree that the body is the most affected region, followed by the condylar process (Johann et al.; Cincik et al.; Larrea-Oyarbide et al.), angle, ramus, coronoid process and mandibular notch (Johann et al.). Cincik et al. and Larrea-Oyarbide et al. claim that the maxilla is the least affected region by the PO. According to Johann et al. on $11.1 \%$ of the cases the $\mathrm{PO}$ occurs in the ramus of mandible region.

The causes of these lesions are still unknown, thus, a lot of etiological factors have been proposed. According to Shafer et al. (1974) it is a real neoplasm, however, other researchers classify the osteomas as a reaction caused by a trauma, since the $\mathrm{PO}$ are generally situated in regions susceptible to trauma, as the base of mandible (Kaplan et al.). According to Regezi \& Sciubba, can be considered trauma: traumatism, reaction to infection and growth anomalies. According to some authors, the combination of trauma and muscular tension could contribute to its development. Thus, the trauma could cause a subperiostic bleeding or local edema, which would increase the periosteum causing an osteogenic reaction which would last through the constant muscular traction (Kaplan et al.) In this case report the osteoma is located at the medial surface of the ramus of mandible on the left side, right below the mandible incision. The medial pterygoid muscle inserts itself in the inferior third of the medial surface of the mandible (Alves \& Cândido 2008, 2009), this way, in our case the lesion is found out of the muscle insertion region and besides, it was not mentioned any occurrence of trauma in the region.
When the osteomas are asymptomatic and small, the best option of treatment is the periodic observation. However, in cases where we can observe a dental malocclusion, the treatment of the osteomas is through the surgery excision (Regezi \& Sciubba).

According to Kaplan et al. the traditional radiography images are most of the time enough for the diagnosis of the osteoma, which is presented as a radiopaque mass with density similar to a normal bone. On the other hand, the potential of the computed tomography exam in offering more information is superior to the conventional radiography. Besides, it has the advantage of eliminating the super positioning, to get high image resolution. The professional can also obtain 3D reconstruction of all the conventional odontological slices (Mozzo et al., 1998; Scarfe et al., 2006; Hintze et al., 2007). In this report, the image obtained through the CTCB offered visualization of the exact location of the osteomaand of the relation of this neoplasm with the adjacent regions, which is essential for adequate surgical planning.

To conclude, we can say that the osteomas in the ramus of mandible are not common neoplasms, which can cause pain and functional aesthetic alterations interfering in the patient's daily routine.

We can also say that the high-resolution images obtained from the CTCB helps the odontologist in the diagnosis and correct/adequate surgical planning.

ALVES, N.; OLIVEIRA, R. J.; DEANA, N. F. \& FREITAS, N. M. Osteoma periférico en la rama mandibular: Reporte de caso. Int. J. Odontostomat., 5(3):215-219, 2011.

RESUMEN: Los osteomas son neoplasias benignas, raras, en la mayoría de los casos asintomáticas, que se constan principalmente de hueso maduro, compacto o esponjoso. De acuerdo a su ubicación en la región maxilofacial, la mandibula, el hueso frontal y los senos paranasales son preferentemente afectados. Describimos un caso de un paciente, sexo femenino, caucásica, que presentaba un aumento de volumen en la región posterior del vestíbulo oral en el lado izquierdo. Al examen clínico se observó una lesión inmóvil, consistente e indolora a la palpación. En la imagen obtenida a través del tomógrafo computado volumétrico Cone Beam (CBCT), se observó una región híperdensa, cilíndrica, con márgenes marcados, ubicada en la cara medial de la rama mandibular izquierda, inferior a la escotadura mandibular. Con base en los datos clínicos y las imágenes obtenidas se puede concluir la presencia de osteoma periférico en región de rama mandibular izquierda.

PALABRAS CLAVE: osteoma periférico, tomografía computada volumétrica Cone-Beam, rama mandibular.

\section{REFERENCES}

Alves, N. \& Cândido, P. Anatomia para o Cirurgião-dentista. $1^{\text {a }}$ ed. São Paulo, Editora Santos, 2008.
Alves, N. \& Cândido, P. Anatomia para o curso de odontologia geral e especifica. 2a ed. São Paulo, Gen-Santos, 2009. 
Bodner, L.; Gatot, A.; Sionvardy, N. \& Fliss, D. M. Peripheral osteoma of the mandibular ascending ramus. J. Oral Maxillofac. Surg., 56:1446-9, 1998.

Cincik, H.; Gungor, A.; Ertugrul, E.; Cekin, E. \& Dogru, S. Peripheral osteoma of the mandible mimicking a parotid mass. Eur. Arch. Otorhinolaryngol., 264:429-31, 2007.

Gardner, E. J. \& Plenk, H. P. Hereditary pattern for multiple osteomas in a family group. Am. J. Hum. Genet., 4:31$6,1952$.

Hintze, H.; Wiese, M. \& Wenzel, A. Cone-beam CT conventional tomography for the detection of morphological temporomandibular joint changes. Dentomaxillofac. Radiol., 36:192-7, 2007.

Johann, A. C.; de Freitas, J. B.; de Aguiar, M. C.; de Araújo, N. S. \& Mesquita, R. A. Peripheral osteoma of the mandible: case report and review of the literature. $J$. Craniomaxillofac. Surg., 33:276-81, 2005.

Kaplan, I.; Calderon, S. \& Buchner, A. Peripheral osteoma of the mandible: A study of 10 new cases and analysis of the literature. J. Oral Maxillofac. Surg., 52:467-70, 1994.

Larrea-Oyarbide, N.; Valmaseda-Castellón, E. L.; BeriniAytés, L. \& Gay-Escoda, C. Osteomas of the craniofacial region. Review of 106 cases. J. Oral Pathol. Med., 37:3842, 2008.

Mozzo, P.; Procacci, C.; Tacconi, A.; Martini, P. T. \& Andreis, I. A. A new volumetric CT machine for dental imaging based on the cone-beam technique: preliminary results. Eur. Radiol., 8:1558-64, 1998.

Regezi, J. A. \& Sciubba, J. J. Patología Bucal: Correlaciones Clinicopatológicas. $3^{a}$ ed. Madrid, McGraw-Hill Interamericana, 2004.

Sayan, N. B.; Uçok, C.; Karasu, H. A. \& Günhan, O Peripheral osteoma of the oral and maxillofacial region: a study of 35 new cases. J. Oral Maxillofac. Surg., 60:1299-301, 2002.

Shafer, W. G.; Hine, M. K. \& Levy, B. M. Patologia bucal. $3^{\text {a }}$ ed. Rio de Janeiro, Interamericana, 1974.

Scarfe, W. C.; Farman, A. G. \& Sukovic, P. Clinical applications of cone-beam computed tomography in dental practice. J. Can. Dent. Assoc., 72:75-80, 2006.

Schneider, L. C.; Dolinksky, H. B. \& Grodjesk, J. R. Solitary peripheral osteoma of the jaws: report of a case and review of literature. J. Oral Surg., 38:452-5, 1980.

Woldenberg, Y.; Nash, M. \& Bodner, L. Peripheral osteoma of the maxillofacial region. Diagnosis and management: a study of 14 cases. Med. Oral Patol. Oral Cir. Bucal, 10:E13942, 2005.

\author{
Correspondence to: \\ Dr. Nilton Alves \\ Rua Humaitá, 1680. CEP 14801-903 \\ Araraquara, São Paulo \\ BRAZIL
}

Email: niltonnalves@yahoo.com.br

Received: 14-08-2011

Accepted: 23-09-2011 